\title{
Detheologizing Dante For a "New Formalism" in Dante Studies
}

In his capital and underutilized "Dante profeta," published in 1941, Bruno Nardi threw down a critical gauntlet, and challenged us to look at the Commedia not through a glass darkly, but face to face. He begins where all such discussions must begin, with the Commedia's most overtly prophetic moments, its political prophecies; situating them within the context of Joachimism and Franciscan spiritualism, he moves to a discussion of medieval attitudes toward prophecy, dreams, and divination. Calling to our attention Albert the Great"s belief that some people "sognano il vero, e, a differenza di altri, hanno visioni veraci, talchè non di rado pronunziano perfino chiarissime profezie" (368), Nardi claims that Dante considered his own experience one such visione verace, ${ }^{1}$ with the result that those who view the poem as a literary fiction misread it: "chi considera la visione dantesca e il rapimento del poeta al cielo come finzioni letterarie, travisa il senso" (392). Moreover, Nardi persists in asking the inelegant questions that are the logical consequence of his position, not only "Si deve dunque credere colle donnicciole di Verona, che Dante scendesse davvero all'Inferno, e davvero salisse all'Empireo?" (392), but even "Ma fu veramente un profeta, Dante?" (405). Given that his answer to the first query is a qualified yes ("Non precisamente questo; bensì che Dante credette gli fossero mostrati in visione l'Inferno, il Purgatorio, il Paradiso terrestre, come veramente sono nella realtà" [392]), Nardi's next step is to take on Croce, for whom to admit such a hallucination on Dante's part is to suggest-impossibly-that the lucid poet was a madman. ${ }^{2}$ If this is madness, says Nardi, Dante was in good company: "dobbiamo confessare che di demenza è impastata la psicologia religiosa; e dementi furono del pari Mosè, Zarathustra e Maometto, dementi Geremia, Ezechiele e san Paolo, non meno del protomartire Stefano e dell'autore dell' Apocalisse" (396). Faced with the obvious similarity 
between Dante's claims and those of previous prophets, Nardi courageously (especially in that he was not an American academic but an Italian ex-priest) vaults the barrier that, by segregating Dante from his precursors, preserves modern believers from the unpalatable necessity of accepting with regard to a medieval poet what they accept from various earlier claimants: namely, authentic divine inspiration. But, if Nardi is more rational than is decorous among believers, he is also more believing than is decorous among rationalists; indeed, the very posing of his final query (to which he offers another qualified assent $)^{3}$ may have limited the influence of his essay.

In this essay I will trace, in broad outline, the history of our recent handling of what I take to be the fundamental question for all readers of Dante's poem: How are we to respond to the poet's insistence that he is telling us the truth? Logically prior to this query stands another that we cannot answer, but on which we may speculate: Did Dante himself believe in the literal truth of those things for which he claims literal truth?

In the wake of the American querelle regarding the allegory of poets versus the allegory of theologians, we seem to have reached an impasse in which the question of Dante's truth claims has been effectively put to one side, begged by some of us, ignored by others, treated as settled by many. This is not to say that the issue is never raised; in our attempts to understand the Commedia's intertextuality, for instance, it is frequently touched upon. ${ }^{4}$ But there is no consensus-merely, in North America, an undiscussed and acritical assumption of allegiance to Charles Singleton's beliefs. As to how we have arrived at such an impasse, I believe that a major cause has been the issue, still unresolved, of the authorship of the Epistle to Cangrande. The impasse has been compounded, moreover, by cultural differences that prevent adherents to essentially the same point of view from benefiting from each other's work: it is my belief that Nardi's contributions regarding "Dante profeta" and Singleton's regarding the Commedia's use of the allegory of theologians are essentially complementary. Since Singleton's position emphasizes the validity of the literal sense as historically true, and the issue of Dante as profeta ultimately goes beyond the specific prophecies within the text to encompass the much larger problem of the poet's view of himself as a teller of truth, these two traditions are in effect parallel 
ways of discussing the one central issue of the poet's truth claims. They have not been viewed as such because neither side has been particularly receptive to the other's mode of framing the question. In the United States we have tended to vex the issue of allegory as a mode, genre, or method, evolving a critical discourse regarding the allegory of the Commedia that barely refers to the text. Hence the Italian accusation that we are engaged in sterile allegorizing at the expense of the poetry - an ironic response given that our insistence on the allegory of theologians was intended to reinvest the literal sense with a poetic worth denied it by the traditional reading based on the allegory of poets. Nor could it be said that we have given the Nardian position its due: in "Dante Theologus-Poeta," Robert Hollander chides those dantisti who "have no difficulty in understanding that Dante claims literal truth for his poem, but then go on to make this Dante a 'prophet,' thus avoiding, as did Bruno Nardi, the way in which the poem is rooted in fourfold exegesis in the name of a single aspect of the biblical possibilities" (64-65). Nardi was not so much avoiding anything as he was formulating the issue in terms that were more congenial to one who was less a literary critic than a historian and philosopher, steeped in the thirteenth century controversies between "true prophets" and "false prophets," whether these charges involve Aristotelians or Franciscans. Indeed, if-with respect to Dante's mode of writing - we were to interrogate the Commedia as much as we have in the past interrogated the Convivio and the Epistle to Cangrande, we would find that Nardi's way of framing the issue of the poet's truth claims is far from inappropriate.

In his later "Il punto sull'Epistola a Cangrande," Nardi moves from stating his case regarding Dante's claims to examining how the poet's claims have traditionally been evaded. In other words, he formulates a theory of evasive reception. Due to its emphasis on reception, and thus on the Trecento commentators-the earliest "recipients" of record-Nardi's theory involves a shift of focus from the Commedia to the Epistle to Cangrande. Noting the accusations of heresy that were levelled at Dante, called a vessel of the devil by the Dominican Guido Vernani, ${ }^{5}$ and culminating in the Dominican ban of 1335 , he points out that all of Dante's early commentators (among whom Nardi places the author of the expository part of the Epistle, a point to which we shall return) feel obliged to protect their poet 
from the charge of heresy. Their defense is invariably based on distinguishing the poeta from the theologus, the literal sense contrived by the poet from the allegorical sense employed by the moralist: "E tutti lo mettono al riparo da questa accusa nello stesso modo, cioè distinguendo quello che Dante scrive come poeta (poetizans) da quello che Dante pensa come teologo 'nullius dogmatis expers,' ossia, in sostanza, fra il senso letterale, intenzionalmente svalutato, e il senso allegorico, il solo vero, cioè quello che si cela sotto il velo delle parole fittizie, 'sotto il velame de li versi strani,' come dice Dante stesso in uno dei luoghi del poema veramente allegorici" (27). The early commentators thus deflected attention from the literal sense and its preposterous claims by intentionally devaluing it, equating it with the allegedly fictitious imaginings of the poet. This stratified division of the text's authorial persona along allegorical lines, with the theologian responsible for the allegorical truth that is hidden under the bella menzogna of the poet's fanciful inventions, creates a deplorable dichotomy that persists to this day, yielding critics who "pur riconoscendo a Dante la tempra di vero poeta, ne svalutano l'altissima ispirazione religiosa da cui la poesia sgorga" (30). In Nardi's opinion, the disastrous lesson on how to protect the poet by devaluing the literal sense of his poem is first provided by the well-intentioned theologian who, he believes, is responsible for the expository section of the Epistle to Cangrande.

At this point, the parallels between Nardi and Singleton become more evident, as do the ironies inherent in our story. Nardi is as determined a defender of the literal sense of the Commedia as is Singleton; like Singleton, he is deeply aware of the significance of the Epistle to Cangrande as a hermeneutic document. But their approach to the document could not be more different. While Singleton grounds his defense of the Commedia's literal sense in an appeal to the Epistle to Cangrande- "The allegory of the Divine Comedy is so clearly the 'allegory of theologians' (as the Letter to Cangrande by its example says it is) that one may only wonder at the continuing efforts made to see it as the "allegory of poets" " (90)—Nardi refuses to acknowledge the Dantesque paternity of much of the Epistle because he believes that it treats the poem's literal sense as mere fictio. In this, Nardi took a particularly idiosyncratic stand, since-as Singleton had in fact astutely observed-it was only to be expected 
that attacks on the allegory of theologians as the Commedia's dominant mode would take the form of attacks on the authenticity of the Epistle, as indeed proved to be the case. ${ }^{6}$ Before turning to the complications caused by Nardi's stand regarding the Epistle, another profound confluence between his ideas and Singleton's should be noted, a confluence that is the logical outcome of their defenses of the poem's literal sense. ${ }^{7}$ Nardi's emphasis on the detrimental effects of separating the theologus from the poeta may surely be considered responsible for the lack of response to his ideas in Italy: Italian dantismo's protectionist attitude toward what it calls the "poetry" is a Crocean legacy, and Croce's reading-motivated by his disgust with deracinated allegorizing-represents in its essence nothing but a willed and consistent application of a method already canonical in Dante studies, to wit the dichotomized theologus-poeta. Although he did not lay as great a stress on the evils of this dichotomy as Nardi, Singleton too was aware of it as a problem, and indeed viewed the matter in a Nardian focus that was not passed on to his heirs, who have instead preserved the dichotomy and privileged the theologusprecisely as Italian critics, who have done the opposite, have accused them of doing. Thus, Singleton writes that "if we must choose between Dante as theologian and Dante as poet, then, I suppose, we take the poet" (86), adding, à propos "Boccaccio and many others [who] have preferred the theologian": "To see the poet as a "theologian' is to see him essentially as one who constructs an 'allegory of poets,' hiding under a veil the truths of theology — a view which has a long history in Dante interpretation" (95).

Both symptom and cause of the deadlock we have reached with respect to the issue of Dante's truth claims (a formulation that I pre$\mathrm{fer}$, in the interests both of clarity and a more ecumenical approach to Dante studies, to either its allegorical or prophetic precursor) are the acrimony and inflexibility displayed by those who, unwittingly, reflect the old dichotomy in extreme form: as Singleton's heirs dig ever more deeply into the cultural and theological humus from which the Commedia grows, they make the poet appear more and more a theologian, unleashing a backlash from those who would have us remember that he is a poet. ${ }^{8}$ As a group, we are interested in the Commedia's poetry, meaning its rhetoric and philology, and in its theology, meaning its moral philosophy, aspects of the poem that 
we keep resolutely apart; we shy away from the underlying crucible where the two coincide-in a poet who models himself on David, the "humble Psalmist," who like David composes a teodia and speaks as scriba Dei, with what he considers a theologically-vested authority. ${ }^{9}$ To the extent that we do speak of these matters, we view them not as prerequisites for all investigation of the Commedia but as independent strands of Dante studies, devoted to allegory, "profetismo," apocalyptic literature, mysticism, and the like. ${ }^{10}$ Greatly to blame for our critical disarray has been what I consider the "red herring" issue of the Epistle to Cangrande's paternity. The linking of the Epistle to the issue of the Commedia's mode of signifying has had the unfortunate effect of allowing the question of the Epistle's authorship to seem decisive for our reading of the poem. This skewing of the critical discourse is implicit in Singleton's contribution, which gives the impression of being most vulnerable in its reliance on the Epistle, and is explicit in Nardi.

The issue of the Epistle's authorship has distracted us from the text we are trying to understand and has bred unnecessary confusion. Thus, Nardi's principal antagonist in the debate over the paternity of the Epistle was Francesco Mazzoni, a scholar who is far from a supporter of the "prophetic" reading of the Commedia; it is ironic that Nardi and Mazzoni should respond to the Epistle in the same way, as in no way inimical to the fictitiousness of the poem it glosses. To complicate matters, in "La 'mirabile visione' di Dante e l'Epistola a Cangrande," Giorgio Padoan entered the fray on Mazzoni's side, in that he undertakes to defend the authenticity of the entire Epistle, but in Nardi's cause: ${ }^{11}$ Nardi denies the authenticity of the second part of the Epistle because he believes that it promotes the idea of the Commedia as mere fictio; Padoan sustains the Epistle's authenticity because he believes that exactly the opposite is true, i.e. that the expository part of the Epistle supports the idea of a Dante who intentionally represented his text's literal sense as true. In contrast to other commentaries on the opening of the Paradiso, which respond to the first canto's audacious patterning of the poet's ascent on St. Paul's raptus, "whether in the body I do not know, or out of the body I do not know, God knows," with cautious appeals to poetic fiction, ${ }^{12}$ Padoan points out that the Epistle to Cangrande contains no such disclaimers: "Il fatto essenziale per questo discorso è 
che nell'Epistola-proprio come abbiamo visto per la Comedia-si afferma esplicitamente che non di viaggio metaforico si tratta, né di immaginazione di fantasia, bensì di vera e propria 'elevatio ad coelum" "(43). Even more telling are the authentic biblical visions invoked by the Epistle as models for the Commedia, "tre esempi biblici di visioni (ancora una volta) realmente avvenute: 1) il raptus al cielo di S. Paolo; 2) la visione che S. Pietro, S. Giacomo e S. Giovanni ebbero della trasfigurazione di Cristo; 3 ) la visione della gloria di Dio avuta da Ezechiele" (44), examples that in turn are buttressed with references to three authorities on visionary experience, Richard of St. Victor, St. Bernard, and St. Augustine.

Prodding us to confront and openly discuss the issues raised by Nardi, Padoan poses the problem of Dante studies: "Ma questo insistere sulla realtà della visione e questo tono profetico sono essi ad imporsi a Dante per la forza insita nel suo stesso realismo e per la foga della sua appassionata polemica, oppure derivano da una scelta deliberata e consapevole dell'autore, da una sua ben meditata convinzione?" (39). Why is it that this question, articulated more than twenty years ago, whose implications broach representational concerns on the one hand and authorial intentionality on the other, still haunts us today? As I have suggested, one of the reasons that Padoan's compelling arguments have not been able to penetrate and focus critical thought as fully as their author would have wished is their connection to the Epistle; to the extent that his arguments engage the Epistle more than the Commedia, and to the extent that they are presented in the context of a defense of the Epistle's Dantesque authorship, they are the more easily shrugged off by those not willing to listen. Moreover, by linking a tangential issue (the Epistle's authorship) to the main issue (the Commedia's mode of signifying) and then blurring the lines between the two, we have allowed the critical waters to become fearfully muddied. A case in point is a recent book by Peter Dronke, in which the author (like Padoan a student of Nardi's) inveighs against the exegetical approach to which we have been giving the label allegory of poets, which he believes ill serves the Commedia's imaginative power. ${ }^{13}$ Following Nardi, he argues that Dante's claims are not derisible in their historical context: "the great prophet-visionaries of the twelfth and thirteenth centuries-Hildegard and Joachim, Mechthild 
and Marguerite-made unflinching claims to truth. I believe it is their kind of claim that Dante makes" (127). However, he argues against Dante's penning of the Epistle, whose author he considers an inept allegorist, and hence against Padoan; ${ }^{14}$ moreover, he lumps Singleton and Hollander among that "majority of scholars since Croce [who] have continued to think of the Commedia in terms of fiction" (127), an assessment that hardly does justice to their positions or strengthens the cause in which he is fighting. Dronke's book, which also conflates Dante's prophetic claims with those of Alanus, without acknowledging that a major tenet of Nardi's supporters has been the distance between Dante and those poets for whom the literal sense is explicitly less important than the allegorical, illustrates the confusion to which our lack of critical consensus has led.

I suggested earlier that, if we were to interrogate the Commedia as we have the Convivio or the Epistle, we would find support for both Nardi and Singleton. Any metatextual study of the Commedia has to come to terms with the poet as truth-teller, and thus with "Dante profeta" in the larger sense. ${ }^{15}$ A further result of a metatextual reading of the Commedia-of interrogating the Commedia regarding itself - will be to collapse the distinctions between the "allegorical" approach and the "prophetic" approach, by suggesting that, from Dante's perspective, they amount to the same thing. ${ }^{16}$ In other words, what one could call Dante's prophetic mode corresponds to Singleton's allegory of theologians or Auerbach's figural mode. By the same token, I am convinced that the Commedia's imitation of God's way of writing, in defiance of all theological protocol, does not require the Epistle to Cangrande or any other external document for its substantiation; the poem itself furnishes sufficient and incontrovertible evidence of how it wants to be read. By this I do not mean to say that I find the Epistle uninteresting; for the record, my sense of it is that it is Dante's. But I do mean to say that its authorship, were the matter one day to be decided against Dante, need not in any way impinge on our reading of the Commedia.

The distance between Nardi and Singleton regards not so much their ideas on how the poem intends to be received as their response to the second of my initial queries; with respect to Dante's view of himself, Singleton presents a less "naive" persona than Nardi, hewing more closely to the Crocean path: "But to attribute to a critical 
and reflective Dante the belief that he was another Aeneas or another St. Paul is simply to unload on him our own disinclination to face the myth directly and to understand it" (78). In this matter, I follow the Nardian school of thought, which I believe in fact "faces the myth more directly"; thus, my approval for Singleton's famous formula that "the fiction of the Divine Comedy" is that it is not a fiction" (62) does not extend to the suggestion that Dante himself thought his poem a fiction. (What Singleton left veiled is elaborated by Hollander, who grafts onto Singleton's perhaps deliberate reticence an ironic poet who "creates a fiction which he pretends to consider not to be literally fictitious, while at the same time contriving to share the knowledge with us that it is precisely fictional" $[86].)^{17}$ In my opinion, Dante knowingly used the means of fictionpoetic and narrative strategies - in the service of a vision he believed to be true, thus creating what he defined a "truth that has the face of a lie" - "un ver c'ha faccia di menzogna." 18 This paradoxical label, which accommodates the menzogna of art within the framework of an artist whose scribal stature guarantees his work's truth, finds its counterpart in a further paradox that I believe furnishes Dante's definition of his poem: the Commedia is a "non falso errore," not a fiction that pretends to be true, but a fiction that IS true. The phrase "nonfalse error," used to describe the ecstatic visions of the terrace of wrath, provides a means to understand Dante's own understanding of his achievement; not polarized as either theologus or poeta, Dante encompasses the aporias and contradictions of a prophetically inspired poem - a work that as art may be error, but that as prophecy is nonfalse-within the rigorous embrace of paradox.

In sum, I believe we must accept Dante's insistence that he is telling the truth and move on to the consequences. Therefore, although we must address the text's self-presentation as true, we must more fundamentally address the critical consequences of such selfpresentation: to wit, the ways in which the text succeeds in presenting itself as true. In other words, the topic at hand is Dante's realism. Although Dante shares with other narrators the concern to authenticate his narrative, his religious pretensions make this concern particularly pressing; for as Morton Bloomfield points out in "Authenticating Realism and the Realism of Chaucer," while discussing the truth claims inherent in all narrative, the "basic problem of all revealed religions 
is just this authentication" (343). Bloomfield further notes that this problem is in the minds of the authors of the Bible, where it articulates itself precisely in the terms that Nardi formulated in "Dante profeta": "The end of Chapter 18 of Deuteronomy frankly discusses the problem of how to distinguish true prophecy from false" (344). This is the node at which the problems of discussing the Commedia intersect with the problems of discussing all realistic narrative: because of its biblical and prophetic pretensions the Commedia poses the basic narrative issue of its truth value in aggravated form. At the same time, however, Dante does not seek to hide the fact that he is crafting the word of God in language; he draws attention to his role as narrator in a multitude of ways, including the celebrated addresses to the reader. It is extremely relevant to our discussion that Auerbach finds in Dante's addresses to the reader the urgency of a prophet; in other words, typically, Dante has used what could have been moments of vulnerability, moments of exposed narrativity, to forge his most authoritative voice. Spitzer rejects Auerbach's insistence on prophecy in favor of a reading that puts the emphasis on mimesis, on the addresses as aids in the reader's visualization and thus in the poet's realism; tellingly, he does not see that Auerbach is able to arrive at his formulation (Dante as a new prophet capable of inventing the essentially new topos of the address to the reader in the service of his prophetic vision) precisely because he had so long been thinking in terms of Dantesque realism, for in Dante the prophetic stance is indissolubly wedded to the poet's concern with achieving supreme mimesis. ${ }^{19}$ The formulation Dante-prophet disturbs Spitzer as one who is interested in seeing how the Commedia works as art; it does not occur to him that in order to see how it works as art, we have first to accept-not believe!-its prophetic claims on its own terms. Only then can we see the pressures such claims exert upon a poet. One of the great problems of studying Dante is reflected in Spitzer's taking to task of Auerbach: critics, like Nardi and Auerbach, who take the poem's pretensions seriously, are criticized for not seeing an artifact, for believing Dante too much. In fact, they are seeing the artifact most clearly, and are on the road to believing Dante least.

The Commedia's remarkable fusion of absolute certainty about content with self-consciousness about the human artistry that is its 
vehicle has continually fostered new variants of the ancient either/or critical stand, variants expressed in the critical language of their day: recently Jesse Gellrich (sounding like a deconstructionist version of Spitzer critiquing Auerbach) has argued against what he calls Singleton's sense of the Commedia as myth in favor of its self-consciousness, claiming that "an awareness of illusion making is inevitable" and that the poem "does not protect itself from such awareness but encourages it" (143). In fact, Dante creates a poem in which such encouragements may constitute one of its most effective forms of protection. As with the addresses to the reader, Dante protects himself most when he seems most exposed; he neutralizes the betrayal of self-consciousness implicit in all narrative authenticating devices by making his authenticating devices outrageously inauthentic. ${ }^{20}$ Gellrich mistakes Singleton's position in an instructive fashion: he accuses Singleton of really thinking that Dante imitated God's way of writing, of falling for the "myth," while Singleton's position was in fact saying that Dante would have us believe that he imitated God's way of writing. In other words, Gellrich conflates what Singleton himself believes with what Singleton says that Dante wants us to believe. This occurs because of the enormous effort required to keep the two apart; one of the effects of Dante's realism-and one of its most insidious forms of self-protection-is that it causes people to think one agrees with him when one paraphrases him (as all teachers of the Commedia know, it is difficult to persuade one's students otherwise) ${ }^{21}$ By the same token, the reverse is also true: Dante's realism causes critics to tend to "believe" Dante without knowing that they believe him, i.e. to pose their critical questions and situate their critical debates within the very presuppositions of the fiction they are seeking to understand. (An example of such behavior is the common defensive move we could call the collocation fallacy, whereby a critic argues that view $\mathrm{x}$ is not possible with regard to soul $\mathrm{x}$, because if it were soul $\mathrm{x}$ would be located elsewhere; arguing thus, we approach the poem through the lens of its own fiction treated as dogma.) One need not be a religious believer to be a narrative believer of the Commedia; as the history of the poem's reception repeatedly demonstrates, many presumably nonnaive readers have proved unable to suspend their suspension of disbelief. 
As a means for slipping out of the paradoxical grip of the poem's claims and counter-claims, I suggest that we read the Commedia less theologically and more practically. The time has come for us to be more interested in how the Commedia works than in what it says; we should examine the formal structures (practising what Gian Biagio Conte calls "una filologia della struttura narrativa" [112]) that manipulate the reader so successfully that even now we are blinded, prevented by the text's fulfillment of its self-imposed goals from fully appreciating its achievements as artifact. What is needed to get some purchase on a poem that has traditionally been read as Fundamentalists read the Bible is not a "new historicism," which is an effective tool vis-à-vis texts that have always been read as texts, i.e. as false, but a "new formalism": a tool that will not run aground on the text's presentation of itself as true. In other words, we must detheologize our reading if we are to understand what makes the theology stick. For the final irony of our tradition of Dante exegesis is that, as a direct result of our theologus-poeta dichotomy, and frequently in the name of preserving the poetry, we have obscured its greatness by accepting uncritically its directives and its premises, its "theology." To the extent that we read as the poet directs us to read we have not fully appreciated the magnificence of his direction. To the extent that we hearken always to what Dante says rather than take note of what he has done, we treat him as he would have us treat him-not as a poet, but as an authority, a "theologian."

In Dante's Poets, I had occasion to note that "If, in Singleton's formula, the fiction of the Comedy is that it is no fiction, then it follows that the strategy of the Comedy is that there is no strategy" (90). My concern now is to more fully identify the workings of this strategy that would deny its own existence. Previously, I used the example of Cacciaguida, whose explanation that the pilgrim has been shown only famous souls, "anime che son di fama note," is frequently cited by critics; less frequently have they noted-Auerbach is one exception that comes to mind-that Cacciaguida's statement is not true..$^{22}$ As I have pointed out, most of the souls we meet in the Commedia are famous because the Commedia has made them famous, and Cacciaguida's anticipation of this process effects a contamination between text and life that is precisely what Dante seeks to achieve. ${ }^{23}$ Another example of this self-denying strategy is the 
inscription on the gate of hell, analyzed by John Freccero, unusual among Dante scholars for his longstanding pursuit of the implications of form, in terms of the poet's successful attempt to "establish the fiction of immediacy" (98). Reminding us that "Vision is the province of the prophet, but the task of the poet is representation" (95), Freccero seeks to "dispel the unexamined assumption, encouraged by the fiction, of an innocent author describing an infernal reality rather than constructing it" (104). Like the representation of God's art on Purgatory's terrace of pride, which confronts the reader with the conundrum of the poet's verisimilar art re-presenting an art defined as the ver itself, ${ }^{24}$ Cacciaguida creates an "optical illusion" within the text, as do the verses that affect to present God's words on the gates of hell. It is important to note that these examples come from all three canticles: on the representational front the poem is neutral; in the mimetic realm collocation does not imply value, as it does in the thematic sphere. The above examples are taken from Inferno, Purgatorio, and Paradiso to make the point that we cannot approach these issues by invoking the theological grid that we have become so accustomed to imposing on the Commedia, whereby whatever happens in hell is "bad," problematic, and whatever happens in heaven is "good," problem-free. Whereas this formulation may be accurate with respect to the text's content, its plot, and therefore the pilgrim, it need not be accurate with respect to its form, and therefore the poet: the Paradiso is not more serene, formally, than the Inferno. ${ }^{25}$

Dante consistently manipulates narrative in ways that authenticate his text, making it appear inevitable, a fatale andare, and conferring upon himself the authority that in fact we have rarely denied him. In the instances just cited, as in so many others, we have listened to what Dante says, accepting it as true-as though he were a "theologian"rather than looking at, and learning from, the gap that exists between what he says and what he has actually wrought. To the extent, then, that we have not dealt with the implications of Dante's claims to be a second St. Paul, a second St. John, we have not put ourselves in a position to fully grasp the genius of his poetry-of its ability to construct a textual metaphysics so enveloping that it prevents us from analyzing the conditions that give rise to the illusion that such a metaphysics is possible. In "The Irreducible Dove," Singleton 
answers the charges of critics who fear that his beliefs with regard to Dante's allegory put him "in danger of succumbing so completely to the illusion of reality in Dante's poem as to forget that it is illusion" (129). Although he did not realize it, preferring as he did to think in terms of restoring a medieval forma mentis that authorized such illusion, and thus being "allowed to recover from the Renaissance, if only for a brief reader's moment" (135), Singleton's attempt to locate the source of the illusion in the fiction that pretends it is not a fiction is a first step to dismantling the Commedia's textual metaphysics. His critics, precisely in proportion to their level-headed and rational refusal to succumb to a preposterous theory about a preposterous claim, reveal themselves to be the more fully duped by an author whose cunning they have not begun to penetrate. We must work to show how the illusion is constructed, forged, made-by a man who is precisely, after all, "only" a fabbro, a maker . . . a poet.

\section{New York University}

\section{NOTES}

1 "Non artificio letterario, ma vera visione profetica ritenne Dante quella concessa a lui da Dio, per una grazia singolare, allo scopo preciso che egli, conosciuta la verità sulla cagione che il mondo aveva fatto reo, la denunziasse agli uomini, manifestando ad essi tutto quello che aveva veduto e udito" (376).

2 Croce comments: "Ma che le meticolose spiegazioni che egli dà sulla configurazione dei luoghi e sui modi del viaggio, e sul tempo che gli occorse per compierlo, e sui fenomeni che osservò, e, soprattutto, le dissertazioni con le quali spiega e giustifica quelle cose immaginate e le tratta come fatti reali che confermano una teoria scientifica e ne sono confermati, rechino prova che esso stesso fosse ingannato dalle proprie immaginazioni e le prendesse per fatti reali, e cadesse in una sorte di allucinazione; questo, sebbene sia stato in varî modi sostenuto, non è per niun conto da ammettere. E non già perché con tale ipotesi s'introdurrebbe nel genio di Dante una troppo grande mistura di demenza e si verrebbe meno al rispetto che gli si deve; ma veramente perché l'ipotesi contrasta alla limpidezza e consapevolezza della mente e dell'animo di lui, e, per di piú, non è necessaria” (61).

3 "Dante fu vero profeta, non perchè i suoi disegni di riforma politica ed ecclesiastica si siano attuati (riconosciamo, anzi, che, dato il corso naturale degli avvenimenti, erano inattuabili, quali si sono rivelati), ma perchè, come tutti i grandi profeti, seppe levare lo sguardo oltre gli avvenimenti che si svolgevano 
sotto i suoi occhi, e additare un ideale eterno di giustizia" (415). Before reaching this concluding generality, Nardi takes Dante's pretensions even more seriously, rebutting the charge that the Florentine's prophecies were unverified by history by pointing out that the same can be said of Old Testatment prophecies: "Si può rispondere che altrettanto accadde per la restaurazione del trono di David, annunziata come imminente dagli antichi profeti" (409).

4 See, for instance, my Dante's Poets. To study Dante's handling of his precursors is necessarily to study his truth claims, since he consistently formulates the difference between his poctry and that of his predecessors in terms of truth versus falsehood. All the more reason, therefore, considering the current interest in Dante's intertextuality, to reexamine our underlying suppositions regarding his mode of signifying.

5 In the opening paragraph of his De reprobatione monarchiae, Vernani speaks of vessels used by the devil, "mendax et perniciosi pater mendacii," that tempt with a beautiful exterior while containing poison within. Among such vessels is the author of the Commedia: "Inter alia vero talia sua [i.e. of the devil] vasa quidam fuit multa fantastice poetizans et sophista verbosus, verbis exterioribus in eloquentia multis gratus, qui suis poetici fantasmatibus et figmentis, iuxta verbum philosophic Boetium consolantis, scenicas meretriculas adducendo, non solum egros animos, sed etiam studiosos dulcibus sirenarum cantibus conducit fraudulenter ad interitum salutifere veritatis" (93). Vernani adopts to his own ends the inside/outside model used by the commentators to point to the allegorical truth beneath poctry's fictitious veil; for him the beautiful exterior leads not to truth but to falsehood. The poetry of the Commedia is likened to the Boethian sirens, who lead away from truth with their "dulcibus cantibus" - a fascinating alignment in light of the unmasked siren of Purgatorio 19. Also intriguing is the fact that Vernani's treatise is addressed to one of the Commedia's early commentators, Graziolo de' Bambaglioli.

6 Singleton notes: "Indeed, with some Dante scholars, so strong has the persuasion been that such a view of the allegory of the Divine Comedy' is the correct one [i.e. that the allegory of poets is the correct one] that it has brought them to question the authorship of the famous letter to Can Grande. This, in all consistency, was bound to occur" (86). See, for instance, Hollander's rebuttal of Scott on this issue (55 n. 36).

7 Neither scholar seems aware of the other; Singleton's 1954 monograph contains no reference to Nardi, and Nardi's 1960 essay makes no mention of Singleton.

8 An example of the former tendency is Anthony K. Cassell. Dante 's Fearful Art of Justice, a work which shows little appreciation for the ways in which poetry undermines theological certitude (see my review in Renaissance Quarterly 38 [1985]: 705-8). On the other side, see Aldo Scaglione's rebuttal of Cassell's reading of Pier della Vigna, "Dante's Poetic Orthodoxy."

9 On Dante as scriba Dei, sce Gian Roberto Sarolli, Prolegomena alla Divina Commedia. In the section entitled "La visione dantesca come visione paolina," 
Sarolli notes that the Commedia, whose "titolo [è] esemplato sulla davidica teodia," belongs to the "genere delle visioni profetiche" (118). On Dante and David, maker of the teodia, see also Dante's Poets 275-78.

10 See, for instance, Nicolò Mineo, Profetismo e apocalittica in Dante, a work that has been insufficiently absorbed into the critical discussion. Sarolli's own emphasis on the esoteric may have helped obscure the general importance of his sense of Dante as a prophetic poet.

11 For Padoan's description of the debate between Mazzoni and Nardi, with full bibliography, see "La 'mirabile visione" " 40-41.

12 Padoan cites Francesco da Buti: '“fu' io': cioè fu' io Dante, e questo si de' intendere ch'elli ci fu intellettualmente, ma non corporalmente, ma finge secondo la lettera ch'elli vi fusse corporalmente" (42).

13 For further discussion, see my review, Renaissance Quarterly 40 (1988): 291 92.

14 While Padoan justifies the Epistle's inclusion of "fictivus" as a "modus tractandi" of the Commedia (51), Dronke takes it as indicating that the Commedia is a fiction, and thus as a sign that the Epistle is not Dante's (127). More frequently, the presence of fictivus has been used to bolster the anti-Singletonians (Hollander 64 n. 53).

15 One of the most interesting elaborations of Nardi in recent years is that of Guglielmo Gorni, who asks "se la profezia, nella Commedia, non ha statuto di frammento entro l'opera, bensì è una struttura latente e persistente, che emerge e quasi si coagula in singoli episodi, in quali punti precisi del poema Dante fa emergere la coscienza metatestuale di questo fatto decisivo nella costruzione della sua 'visione'?" (50).

16 An example of a metatextual reading that, I believe, bears out this assertion is my "Dante's Heaven of the Sun as a Meditation on Narrative."

17 Hollander's incongruous sense of Dante as ironic, parodic, and humorous in these matters is the logical consequence of his refusal to believe that Dante believes; thus, with respect to the Geryon episode's insistence on veracity, he comments: "One senses behind Dante's passage an authorial wink, lest we take it for a nod: 'I know you won't believe this (why should you? - I don't either), but the convention of my poem compels me to claim historicity even for such as Geryon'" (76). The same logical necessity leads to a singularly unsatisfying response to the question of why Dante chooses to use the allegory of theologians in the first place: "The answers that have been offered (to make his poem 'more true,' to be in closer accord with the theology it professes), while being basically acceptable, have missed, I believe, the central point. Dante's choice reflects his own engagement in the battle against poetry which is closely identified with St. Thomas and the Dominican Order" (84).

18 For the implications of this verse, see Dante's Poets 214 and passim.

19 See "Dante's Addresses to the Reader" and "The Addresses to the Reader in the Commedia." I quote from the latter: "It would seem strange to me that Professor Auerbach, the author of such excellent works as "Dante the 
Poet of This World" and "Mimesis" did not think (or not primarily think) of the possibility that Dante's addresses are meant to be in the service of precisely!-Mimesis, of the description of the other world carried out with the vividness, or realism, with which things of this world may be described, and I can attribute Auerbach's failure to draw the consequences of Mimesis for our particular problem only to that understandable tendency of the scholar to tire of those very categories he has most superbly developed in other works of his. 'The authority and the urgency of a prophet'- this interpretation smacks more of the arrogantly heiratic solemnity of Stefan George or of certain would-be religious poses applied to Dante by certain American critics than of the urbane thisworldliness and the subtle flair for artistry and its techniques that have ever characterized Erich Auerbach's writing" (158).

20 The psychology that informs Dante's application of what I call the Geryon principle, whereby the least credible of his representations is supported by the most unyiclding and overt of authorial interventions (for elaboration, see my "Arachne, Argus, and St. John"), is well understood by Spitzer: "To give the reader 'something to do' about a matter difficult to imagine is a psychological inducement to make him accept this subject matter" (152). By the same token, Bloomfield anticipates a good deal of Gellrich's book when he writes "all authenticating devices not only authenticate but also call attention to the need for authentication and hence to the inauthenticity of the work of art" (340).

2I Unfortunately, it is aiso difficult to persuade one's colleagues otherwise; in my own case, I would disagree with John G. Demaray's assessment that I take a "modern idealist posture that the 'only external referent' upon which Dante based the truth of the Commedia is a transcendent God" (42 note). That is what Dante tells us, not what I believe.

22 "Of the characters which appear in it [the Commedia], some belong to the recent past or even to the contemporary present and (despite Par. 17.136-38), not all of them are famous or carefully chosen" (184).

23 Dante's Poets 282.

24 See my "Ricreare la creazione divina: l'arte aracnea della cornice dei superbi."

25 For Dante's awareness of the problems inherent in representing paradise, see "Dante's Heaven of the Sun as a Meditation on Narrative." Since one of my three examples is provided by another critic, it behooves me to indicate the differences in our formulations. In Freccero's reading form remains subservient to theology, as is indicated by the fact that his view of Dantesque mimesis distinguishes very discretely between the various canticles. Thus, he begins "Infernal Irony" by I) invoking the De Genesi ad litteram's three kinds of vision-corporeal, spiritual, and intellectual-as analogies for the kinds of representation found in each canticle, and by 2) suggesting that "mimesis is peculiarly infernal and represents Dante's effort to render corporeal vision" (96). I do not agree: while irony may be peculiarly infernal, mimesis is a problem for the poet throughout the pocm; it is a problem that if anything 
escalates as the poem proceeds. To associate the three canticles with Augustine's three types of vision is to address the matter of their content, not the matter of their form.

\section{WORKS CITED}

Auerbach, Erich. Mimesis. 1946. Princeton: Princeton UP, 1974. . "Dante's Addresses to the Reader." Romance Philology 7 (1954): 268-278.

Barolini, Teodolinda. Dante's Poets: Textuality and Truth in the Comedy. Princeton: Princeton UP, 1984.

. "Dante's Heaven of the Sun as a Meditation on Narrative." Lettere Italiane 40 (1988): 3-36.

"Ricreare la creazione divina: l'arte aracnea della cornice dei superbi." Saggi danteschi americani. Eds. Robert Hollander and Gian Carlo Alessio. Milano: Franco Angeli, 1989.

. "Arachne, Argus, and St. John: Transgressive Art in Dante and Ovid.” Mediaevalia 13 (1989).

Bloomfield, Morton W. "Authenticating Realism and the Realism of Chaucer." Thought 39 (1964): 335-358.

Cassell, Anthony K. Dante's Fearful Art of Justice. Toronto: U of Toronto P, 1984.

Conte, Gian Biagio. Il genere e i suoi confini. Torino: Stampatori, 1980.

Croce, Benedetto. La poesia di Dante. 2nd ed. rev. Bari: Laterza, 1921.

Demaray, John G. Dante and the Book of the Cosmos. Philadelphia: The American Philosophical Society, 1987.

Dronke, Peter. Dante and Medieval Latin Traditions. Cambridge: Cambridge UP, 1986.

Freccero, John. "Infernal Irony: The Gates of Hell." 1984. Dante: The Poetics of Conversion. Ed. Rachel Jacoff. Cambridge: Harvard UP, 1986.

Gellrich, Jesse M. The Idea of the Book in the Middle Ages. Ithaca: Cornell UP, 1985.

Gorni, Guglielmo. "Spirito profetico duecentesco e Dante." Letture Classensi 13 (1984): 49-68.

Hollander, Robert. "Dante Theologus-Poeta." 1976. Studies in Dante. Ravenna: Longo, 1980.

Matteini, Nevio, ed. Il più antico oppositore politico di Dante: Guido Vernani da Rimini. Testo critico del De Reprobatione Monarchiae. Padova: CEDAM, 1958.

Mineo, Nicolò. Profetismo e apocalittica in Dante. Catania: U di Catania, 1968.

Nardi, Bruno. "Dante profeta." Dante e la cultura medievale. 2nd ed. rev. Bari: Laterza, 1949.

"Il punto sull’Epistola a Cangrande." Lectura Dantis Scaligera. Firenze: Le Monnier, 1960.

Padoan, Giorgio. "La 'mirabile visione' di Dante e l'Epistola a Cangrande." 
1965. Il pio Enea, l'empio Ulisse. Ravenna: Longo, 1977.

Sarolli, Gian Roberto. Prolegomena alla Divina Commedia. Firenze: Olschki. 1971.

Scaglione, Aldo. "Dante's Poetic Orthodoxy: The Case of Pier della Vigna." Lecura Dantis (U of Virgina) 1.1 (1987): 49-59.

Singleton, Charles S. Commedia: Elements of Sucture. Cambridge: Harvard UP, 1954.

35.

Spitzer, Leo. "The Addresses to the Reader in the Commedia." Italica 32 (1955): 143-165. 